UDC $342.725(075)$

Submitted: 17.09.2020

LBC 81.2(2)я73

Accepted: 22.01.2021

\title{
INSTITUTIONAL FRAMEWORK FOR LANGUAGE POLICY IN RUSSIA: VIEWS FOR THE FUTURE ${ }^{1}$
}

\author{
Ol'ga B. Yanush \\ Kazan State Power Engineering University, Kazan, Russian Federation \\ Nail' M. Mukharyamov \\ Kazan State Power Engineering University, Kazan, Russian Federation
}

\begin{abstract}
Introduction. The study of language planning and policy (LPP) involves the cross-disciplinary interaction of applied linguistics and political science. The need for this is increasing especially in relation to the regulatory and organizational aspects of language regulation in the conditions of modern Russia. Methods and materials. The authors use the techniques of systems analysis and approaches of political institutionalism: normative, rational choice, theory of organizations, historical, constructivist, network. To study the materials of official documents and legislative acts, the method of textual analysis is used. Academic works of foreign and Russian authors are used through the prism of discourse analysis. Materials related to the activities of agencies and actors in the field of LPP, characterized from a structural and functional point of view. Analysis. The normative and agentive properties of LPP in the modern conditions of Russia and its regions are considered by the authors of the article through analytical procedures proposed by foreign scientists. Many developments from Englishlanguage works in this area can be adapted to the tasks of studying political-linguistic relations, taking Russian specifics into account. The ratio of institutional and conversational types of linguistic interactions is considered as a subject of linguistic pragmatics. The main subject of analysis is formal regulatory complexes and agencies specializing in this area. The analysis undertaken by the authors of the article leads to the conclusion that there is no sustainable institutional LPP model in the Russian situation. This applies, in particular, to the de facto and de jure characteristics of bilingualism as a strategic priority proclaimed at the beginning of the $20^{\text {th }}$ century. In the latest official texts, the emphasis is on strengthening the position of the Russian language. Further, the body of Russian and regional legal acts is marked by features of rhetoric and excessive symbolism. The prospects for institutionalization here are associated with overcoming such normative dysfunctions. Results. The article draws conclusions about the desirability of conceptualizing LPP within the framework of a separate state doctrinal document, as well as a system of information support and implementation of the principles of language cultivation and management.
\end{abstract} setting.

Key words: institutions, language policy, institutional model, cultural and linguistic diversity, strategic goal-

Citation. Yanush O.B., Mukharyamov N.M. Institutional Framework for Language Policy in Russia: Views for the Future. Vestnik Volgogradskogo gosudarstvennogo universiteta. Seriya 4. Istoriya. Regionovedenie. Mezhdunarodnye otnosheniya [Science Journal of Volgograd State University. History. Area Studies. International Relations], 2021, vol. 26, no. 3, pp. 134-146. (in Russian). DOI: https://doi.org/10.15688/jvolsu4.2021.3.12

УДК $342.725(075)$

Дата поступления статьи: 17.09.2020

Дата принятия статьи: 22.01.2021

ББК $81.2(2)$ я73

ИНСТИТУЦИОНАЛЬНЫЕ ОСНОВЫ ЯЗЫКОВОЙ ПОЛИТИКИ В РОССИИ: ВИДЫ НА БУДУЩЕЕ 1

\author{
Ольга Борисовна Януш
}

Казанский государственный энергетический университет, г. Казань, Российская Федерация 


\section{Наиль Мидхатович Мухарямов}

Казанский государственный энергетический университет, г. Казань, Российская Федерация

Аннотация. В статье рассматриваются некоторые узловые характеристики предмета, связанного с исследовательскими разработками и практическим проведением мер регулирования политико-языкового устройства современной России, с режимами этнолингвистического многообразия страны. Это - приоритетная, жизненно важная составляющая публичной политики в ее культурно-коммуникативных измерениях. Становление соответствующих нормативных, структурно-организационных, исторических и конструктивистских комплексов, задающих правила и процедуры в области языковых отношений, - это многомерный процесс, нуждающийся как в аналитически-проектном освоении, так и в эффективной реализации. Множественность институциональных качеств в языковом функционировании и во властно-управленческом воздействии на него выражается в интегральных характеристиках политики как таковой, а также в отдельных ее компонентах: в корпусе нормативно-правовых текстов, в дискурсе и институциональных моделях, или государственных стандартах (применительно, прежде всего, к образовательной сфере). В современных российских условиях такие нормативные и организационные комплексы нуждаются в концептуальном переосмыслении. Это связано, прежде всего, с доктринальным определением концепта «языковая политика» как такового в формате законодательных актов и в документах стратегического планирования, что позволит восполнить дефицит целеполагания. Официальный дискурс о языках народов страны нуждается в избавлении от избыточных свойств декларативности, риторичности, ритуальной символизации. Структурно-организационные параметры языкового регулирования, представленные преимущественно органами консультативного и совещательного профиля, целесообразно дополнить полномочными ведомствами, наделенными координирующими компетенциями. Авторы приходят к выводам о необходимости по-новому сформулировать стратегическое видение, информационно-аналитическое оснащение проводимой в этой области политики за счет адекватных данных о реальных социолингвистических состояниях. Меры проводимой языковой политики целесообразно дополнить также системной работой в плане языкового культивирования и языкового менеджмента при решающей роли правящих и не правящих элит как носителей языковой авторитетности.

Ключевые слова: институты, языковая политика, институциональная модель, культурно-языковое многообразие, стратегическое целеполагание.

Цитирование. Януш О. Б., Мухарямов Н. М. Институциональные основы языковой политики в России: виды на будущее // Вестник Волгоградского государственного университета. Серия 4, История. Регионоведение. Международные отношения. -2021. - Т. 26, № 3. -C. 134-146. - DOI: https://doi.org/10.15688/jvolsu4.2021.3.12

Введение. Исследование принципов и способов управленческого воздействия на языковое устройство общества, на состояние социально-коммуникативных отношений и сред это кросс-дисциплинарная область научных интересов. Еще на самых ранних этапах обособления этого направления языкознания один из признанных «классиков» темы Э. Хауген писал в конце 1950-х гг., что языковое планирование - «это один из видов языковой политики, и потому нуждается в прозрениях политической науки относительно путей и возможностей завоевания доверия руководимых», также, как и антропологии, социологии, психологии, этики и философии. Прикладная лингвистика, «чтобы войти в макролингвистику, не имеет права отворачиваться от макромира - общества, в котором мы живем, говорим и пишем» $[12$, с. 470]. Это суждение самым заметным образом усиливается в своей актуальной значимости в связи с выдвижением институционализма на авансцену политической науки наших дней.

Методы и материалы. Авторы используют приемы системного анализа и подходы политического институционализма - нормативный, рационального выбора, теории организаций, исторический, конструктивистский, сетевой. Для изучения материалов официальных документов и законодательных актов применяется метод текстуального анализа. Академические работы зарубежных и российских авторов используются сквозь призму дискурсивного анализа. Материалы, связанные с деятельностью агентств и акторов в области языковой политики и планирования, характеризуются со структурно-функциональной точки зрения.

Анализ. Язык, политика и институты в аналитических ракурсах. Использование языка изначально, еще с архаичных времен, всегда подлежало регламентациям разными способами и на основе определенных нор- 


\section{ПОЛИТИЧЕСКИЙ ПРОЦЕСС В СОВРЕМЕННОЙ РОССИИ}

мативных порядков и комплексов. Первобытные суеверия и основанное на мифах мировосприятие предполагало запреты на основе табу древнейшей, как следует из лингвистических представлений, формой цензуры. В контекстах вероисповедного сознания формировались соответствующие формы цензуры - религиозной и морально-этической, а на подступах к обществу Модерна - идеологической. Вмешательство в язык может быть показано как «отнесение табу к уровню конвенциональных, нравственно обусловленных вето, а цензуры и идеологии политкорректности - к институционально регламентированным» $[11$, с. 55-56, 66].

Языковое функционирование, уровни и формы речевых взаимодействий во многих своих аспектах содержат свойства институциональности. Существуют множественные приемы концептуализации практики взаимной обусловленности языка, с одной стороны, и институтов разного порядка (социальных, культурных, правовых, административных, политических...), с другой стороны. Представители тех или иных академических дисциплин, субдисциплин и кросс-дисциплинарных исследовательских областей оперируют в рамках своих аналитических перспектив.

Традиционный - социолингвистический подход - придерживается своих предметных проекций.

Во-первых, в рамках языкознания по традиции принято разграничивать сферы общения на аморфные (нерегламентированные, неофициальные, некодифицированные, личностно мотивированные, бытовые и пр.) и регламентируемые (упорядоченные, нормированные, обусловленные статусными характеристиками, стилистически организованные, регулируемые со стороны общества и государства, в том числе так называемые «доминантные» сферы образования и массовой коммуникации) [4, с. 463]. В сходной логике и в контексте конверсационного анализа вербальную интеракцию подразделяют на ординарную (интуитивную, повседневную, семейно-бытовую, связывающую друзей и знакомых, происходящую за рамками институциональных установлений и настроек) разновидность, с одной стороны, и институциональный в различных степенях - разговор, с другой стороны. В первом случае участники коммуникации могут свободно чередовать приемы обще- ния и варьировать направленность и повороты речевого обмена. Институциональное общение предполагает определенные фазы - обозначаемые начало и завершение эпизода общения, заранее заданный характер формальных процедур. Этот вариант включает, например, участие в коммуникации в учебных классах и аудиториях, на рабочих местах, в служебных совещаниях, во время судебных слушаний, на врачебных приемах и пр. [16, p. 254-255]. Иногда линия различения проводится между языковым употреблением в социальном и индивидуальном вариантах, а также - между институциональными и психологическими его видами [18, p. 66]. Стоит отметить, что названные различения относятся к языковым ситуациям любого типа (одно-, дву- и многоязычным) и не отражают специфики функционального распределения языков в сложносоставных социально- и этно-коммуникативных средах.

Таким образом, фактор институциональности по-разному выражен в зависимости от жанровых и стилистических параметров языкового функционирования.

Во-вторых, аспекты, связанные с институтами, рассматриваются с точки зрения «представленности» того или иного языка в конкретных сферах общественных отношений. В данном случае устанавливается место языка и его ранг в плане того, насколько он полифункционален, каков его коммуникативный ранг, или, иначе говоря, в какой степени этот идеоэтнический код (в обиходе обозначаемый как «национальный язык») закреплен в секторальном смысле. Это - сферы и институты образования разных ступеней, роль языка как предмета и/или средства обучения, наука, книгоиздание и масс-медиа (печатная периодика и телерадиовещание), литература и искусство, институты духовного производства в целом, Интернет, сфера (и, разумеется, институты) власти и управления, законотворчества, судопроизводства, административно-управленческие структуры, бизнес и производства, торговля. Особо следует выделить область религиозных отношений и вероисповедной практики. Иногда эти параметры социолингвистических состояний квалифицируются как уровни институциализированности языка [15, p. 1656].

Далее, применительно к рассматриваемой предметной области, важны те контек- 
сты, которые входят в сферу интересов политического анализа, в том числе - с точки зрения институциональных подходов. Соответствующие смысловые грани включают разнящиеся интерпретации и, следовательно, концептуальные образы институтов и версии институционализма в их специфику. Исследователи выделяют социально-деятельностный (устойчивые практики, основанные на системе норм и правил, на социально-профессиональных ролях), поведенческий («модели поведения, которым обеспечена общественная поддержка»), организационный (структурирование и регулирование сводом формальных правил), социально-конструктивистский (неоинституциональный) подходы к предмету [9, с. 214]. В других вариантах типологическая картина строится на дифференциации концептуальных вариантов институционализма и роли институтов в политическом процессе - нормативный, рационального выбора, теория организаций, исторический, конструктивистский, сетевой, международных отношений [10, с. 125].

Познавательная ситуация в приложениях к политико-языковым отношениям, курсу проводимого политико-управленческого воздействия на языковое устройство общества, складывающимся языковым режимам на международных и национальных, а также субнациональных или региональных горизонтах определяется, следовательно, тем, насколько приведенные аналитические схематики релевантны, какие эвристические перспективы они сулят.

Очевидный, лежащий на поверхности предмета, и, можно сказать, тривиальный аналитический ход заключается в установлении организационно-институциональных структур и обстоятельств, присущих проводимой языковой политике. В своего рода «ведомственной», аппаратной или бюрократической логике вопрос формулируется как установление статуса, профиля, полномочий и мандатов тех агентств, органов и учреждений, комитетов, департаментов, комиссий, которые ответственны за языковую политику.

Далее вполне логичной выглядит и такой предметный ракурс, как уровни и формы субъектности применительно к языковой политике. В англоязычных научных разработках используется схема исследования языкового планирования, предложенная Р. Купером: какие акторы (формальные элиты, влиятельные фигуры, контрэлиты, не-элитные группы, выполняющие функции имплементации языковой политики).

При этом по параметру акторов - выделяются также действия «сверху - вниз» и «снизу - вверх», или, по-другому, действующие лица, обладающие властными полномочиями и таковыми не обладающие [13, p. 98; 17, p. 52-58].

В рассматриваемом предметном поле, таким образом, следует различать институционально оформленные виды политико-языкового участия и такие способы, которые осуществляются вне особым образом обеспеченных оснований (в организационном, нормативном или авторизованном в политическом плане).

Очевидно, что вопрос о составе акторов, их мотивациях, исполняемых ими ролях располагается в сердцевине исследовательской повестки, касающейся институтов языковой политики.

Далее серьезные познавательные задачи предстают во взаимно направленных перспективах - институты в языковых отношениях и языковой политике, с одной стороны, и языковые атрибуты, способы существования политических институтов, с другой стороны. Очевидно, что функционирование этих институтов - в каких бы смыслах они не рассматривались (нормативных, организационных, поведенческих, конструктивистских), обладает семиотической природой. Их деятельность в самой высокой степени вербальна. Это значит, что языковая политика прямо или косвенно воздействует на эту жизненно важную сторону политической действительности.

Наконец, возможности применения институциональных подходов к проблематике политико-языковых отношений и властно-управленческому регулированию языковой жизни какого бы то ни было общества следует оценивать не в абсолютных или безусловных категориях. Какие-то аспекты темы сомнений вызывать не могут. Это касается и структурно-организационных, и регулятивных, процедурных аспектов, и «правил игры», и конструктивистских принципов. Однако парадигма рационального выбора, по-видимому, обладает ограниченной применимостью к области 


\section{ПОЛИТИЧЕСКИЙ ПРОЦЕСС В СОВРЕМЕННОЙ РОССИИ}

политико-языковых материй. Это связано с тем, что представления и установки людей, касающиеся из языкового выбора и языкового поведения, содержат аффективные измерения, которым подчас принадлежит решающее значение. По-особенному явственно это проявляется в тех случаях, когда язык становится не просто инструментом общения, практикуется в контексте коммуникативной утилитарности, а воспринимается символически и служит выражением идентичности.

Если кратко суммировать сказанное, то определяющим признаком языковой политики, сформированной и проводимой в качестве самостоятельного направления публичной политики, если угодно, показателем ее «зрелости» является соответствующая институциональная модель. Эта категория, начиная со сравнительно недавнего времени, артикулируется в зарубежной исследовательской практике, связанной с регулятивными составляющими предметного поля политической лингвистики. Связанные с этим подходы обладают двоякой логикой, когда институциональность видится как интегральная характеристика языковой политики в целом, и - соответствующая модель трактуется в качестве одного из структурных элементов всего комплекса - регистра - политико-языкового регулирования:

(1) документы, касающиеся языковой политики, или законодательные акты;

(2) дискурс относительно языковой политики, или меморандумы относительно правовых текстов;

(3) институциональная модель языковой политики, или государственные стандарты [14, p. 169-174].

Языковая политика в современной России: перспективы институционального развития. Состояние институциональной оснащенности властно-управленческого воздействия на языковые отношения и культурно-языковое многообразие в нынешних российских условиях отмечено определенными свойствами амбивалентности.

Планируются и предпринимаются во множестве меры, рассчитанные на укрепление позиций русского языка как государственного языка Российской Федерации и языка межнационального общения, как языка высокого мирового ранга. В изменениях Основного закона страны, которые были одобрены в ходе общероссийского голосования 1 июля 2020 г., русский язык в ст. 68 закреплен как «язык государствообразующего народа, входящего в многонациональный союз равноправных народов». Одновременно с этим подтверждено право республик устанавливать свои государственные языки, используемые наряду с русским языком, народам страны гарантируется право на сохранение родного языка и создание условий для его изучения и развития.

На самом высоком уровне сформулирована установка - языковая политика, как указывает В.В. Путин, «должна быть продуманной, сбалансированной и актуальной, отвечать современным тенденциям, чутко и гибко реагировать на их изменения» [3].

Наряду с этим правомерным, но открытым остается вопрос: насколько конституирована государственная языковая политика в сегодняшней России в виде стратегически фундированного, официально артикулированного и институционально оснащенного направления публичной политики.

Следует начать с того, что это измерение политико-административной деятельности еще по существу не получило системного терминологического закрепления и концептуализации (в отличие от «национальной» и «культурной» политик) в корпусе документов стратегического планирования.

С институциональной точки зрения можно констатировать структурно-организационную недостаточность и разобщенность в управленческом дизайне как таковом. В приводимых здесь таблицах значатся главным образом органы консультативно-совещательной компетенции (см. табл. 1 и 2). Отдельного государственного ведомства как средоточия всей полноты ответственности за проводимую языковую политику с адекватным объемом полномочий и ресурсов не существует. Как отмечал советник Президента России по вопросам культуры В.И. Толстой, «...не может быть языковая политика государства бесхозной (выделено нами. - О. Я., Н. М.)». Опыт укрепления позиций французского, немецкого, испанского и китайского языков как на своей родине, так и в мире, согласно мнению этого государственного деятеля, свидетельствует, что успех достигается только тогда, когда «есть единый центр управления этой деятельностью» [3]. 


\section{Таблица 1. Институты языковой политики федерального уровня}

\section{Table 1. Institutes of language policy at the federal level}

\begin{tabular}{|c|c|c|}
\hline Наименование института & Дата создания, вид НПА & Профиль деятельности \\
\hline $\begin{array}{l}\text { Совет при Президенте Российской Фе- } \\
\text { дерации по русскому языку }\end{array}$ & $\begin{array}{l}\text { Указ Президента Российской Федерации } \\
\text { от } 9 \text { июня } 2014 \text { г. № } 409 \text { (с изменениями } \\
\text { на } 12 \text { августа } 2019 \text { г.) } \\
\text { Действующщий }\end{array}$ & $\begin{array}{l}\text { Координационный } \\
\text { Совещательный }\end{array}$ \\
\hline $\begin{array}{l}\text { Правительственная комиссия по рус- } \\
\text { скому языку }\end{array}$ & $\begin{array}{l}\text { Постановление Правительства Россий- } \\
\text { ской Федерации от } 8 \text { августа } 2020 \text { г. } \\
\text { № } 1197 \\
\text { Действующщий }\end{array}$ & Координационный \\
\hline $\begin{array}{l}\text { Экспертно-консультационный совет по } \\
\text { продвижению и поддержке образования, } \\
\text { науки и русского языка за рубежом при } \\
\text { Федеральном агентстве по делам Со- } \\
\text { дружества Независимых Государств, со- } \\
\text { отечественников, проживающих за ру- } \\
\text { бежом, и по международному гумани- } \\
\text { тарному сотрудничеству }\end{array}$ & $\begin{array}{l}\text { Приказ Федерального агентства по де- } \\
\text { лам Содружества Независимых Госу- } \\
\text { дарств, соотечественников, проживаю- } \\
\text { щих за рубежом, и по международному } \\
\text { гуманитарному сотрудничеству от } \\
9 \text { февраля } 2018 \text { г. № } 0016 \text {-пр } \\
\text { Действующңий }\end{array}$ & $\begin{array}{l}\text { Консультационный } \\
\text { Координационный }\end{array}$ \\
\hline $\begin{array}{l}\text { Координационный совет по развитию } \\
\text { системы тестирования граждан зарубеж- } \\
\text { ных стран по русскому языку Министер- } \\
\text { ства образования Российской Федерации }\end{array}$ & $\begin{array}{l}\text { Приказ Министерства образования Рос- } \\
\text { сийской Федерации от } 5 \text { мая } 2000 \text { г. } \\
\text { № } 1316 \\
\text { Действующций }\end{array}$ & $\begin{array}{l}\text { Координационный } \\
\text { Консультативный }\end{array}$ \\
\hline $\begin{array}{l}\text { Совет по русскому языку при Прави- } \\
\text { тельстве Российской Федерации }\end{array}$ & $\begin{array}{l}\text { Постановление Правительства РФ от } \\
5 \text { ноября } 2013 \text { г. № } 992 \\
\text { Упразднен (Постановление Правитель- } \\
\text { ства РФ от } 22 \text { сентября 2018 г. № 1123) }\end{array}$ & Кон сультативный \\
\hline $\begin{array}{l}\text { Совет Росаэронавигации по вопросам } \\
\text { преподавания, изучения и использова- } \\
\text { ния английского языка }\end{array}$ & $\begin{array}{l}\text { Приказ Федеральной аэронавигацион- } \\
\text { ной службы от } 13 \text { ноября } 2006 \text { г. № } 78 \\
\text { Действующций }\end{array}$ & Консультативный \\
\hline
\end{tabular}

\section{Таблица 2. Институты языковой политики регионального уровня}

\section{Table 2. Institutes of language policy at the regional level}

\begin{tabular}{|c|c|c|c|}
\hline $\begin{array}{l}\text { № } \\
\text { II/II }\end{array}$ & Наименование института & Дата создания, вид НПА & $\begin{array}{c}\text { Профиль } \\
\text { деятельности }\end{array}$ \\
\hline 1 & $\begin{array}{l}\text { Общественный совет по развитию кал- } \\
\text { мыцкого языка }\end{array}$ & $\begin{array}{l}\text { Указ Главы Республики Калмыкия от } \\
3 \text { августа } 2012 \text { г. № } 103 \text { (с изменениями } \\
\text { на 24.12.2018) } \\
\text { Действующцй }\end{array}$ & Консультативный \\
\hline 2 & $\begin{array}{l}\text { Совет по русскому языку и языкам на- } \\
\text { родов Дагестана при Главе Республики } \\
\text { Дагестан }\end{array}$ & $\begin{array}{l}\text { Указ Главы Республики Дагестан от } \\
9 \text { февраля 2015 г. № } 16 \text { (с изменениями } \\
\text { на 24.07.2017) } \\
\text { Действующъий }\end{array}$ & Совещательный \\
\hline 3 & $\begin{array}{l}\text { Координационный совет по вопросам } \\
\text { сохранения и развития коми-пермяц- } \\
\text { кого языка и культуры при Министер- } \\
\text { стве по делам Коми-Пермяцкого округа } \\
\text { Пермского края }\end{array}$ & $\begin{array}{l}\text { Приказ Министерства по делам Коми- } \\
\text { Пермяцкого округа Пермского края от } \\
31 \text { августа } 2010 \text { г. № СЭД-50-01-05-135 } \\
\text { (с изменениями на } 5 \text { марта } 2018 \text { г.) } \\
\text { Действующчий }\end{array}$ & Координационный \\
\hline 4 & $\begin{array}{l}\text { Совет по русскому языку при Губерна- } \\
\text { торе области }\end{array}$ & $\begin{array}{l}\text { Постановление Губернатора Вологод- } \\
\text { ской области от } 20 \text { марта } 2015 \text { г. № } 127 \\
\text { (с изменениями на } 26 \text { декабря } 2018 \text { г.) } \\
\text { Действующций }\end{array}$ & $\begin{array}{l}\text { Коллегиальный } \\
\text { Совещательный } \\
\text { Координационный }\end{array}$ \\
\hline 5 & $\begin{array}{l}\text { Экспертно-консультативный совет по } \\
\text { сохранению и развитию языков (кабар- } \\
\text { дино-черкесского и карачаево-балкарс- } \\
\text { кого) коренных народов Кабардино- } \\
\text { Балкарской Республики при Правитель- } \\
\text { стве Кабардино-Балкарской Республики }\end{array}$ & $\begin{array}{l}\text { Распоряжение Правительства Кабардино- } \\
\text { Балкарской Республики от } 21 \text { октября } \\
2013 \text { г. № 584-рп (с изменениями на } \\
17.11 .2015) \\
\text { Действующий }\end{array}$ & $\begin{array}{l}\text { Совещательный } \\
\text { Консультативный }\end{array}$ \\
\hline
\end{tabular}




\section{ПОЛИТИЧЕСКИЙ ПРОЦЕСС В СОВРЕМЕННОЙ РОССИИ}

\section{Продолжение таблищь 2}

\section{Continuation of Table 2}

\begin{tabular}{|c|c|c|c|}
\hline $\begin{array}{l}\text { № } \\
\text { ПI/II }\end{array}$ & Наименование института & Дата создания, вид НПА & $\begin{array}{c}\text { Профиль } \\
\text { деятельности }\end{array}$ \\
\hline 6 & $\begin{array}{l}\text { Редакционный совет по развитию ма- } \\
\text { рийской литературы и марийского ли- } \\
\text { тературного языка }\end{array}$ & $\begin{array}{l}\text { Распоряжение Главы Республики Ма- } \\
\text { рий Эл от } 4 \text { марта } 2016 \text { г. № 32-рг (с из- } \\
\text { менениями на 17.04.2017) } \\
\text { Действующций }\end{array}$ & $\begin{array}{l}\text { Координационный } \\
\text { Консультативный }\end{array}$ \\
\hline 7 & $\begin{array}{l}\text { Совет по русскому языку при Главе } \\
\text { Республики Ингушетия }\end{array}$ & $\begin{array}{l}\text { Указ Главы Республики Ингушетия от } \\
13 \text { июля } 2016 \text { г. № } 145 \text { (с изменениями } \\
\text { на } 19 \text { декабря } 2017 \text { г.) } \\
\text { Действующий }\end{array}$ & $\begin{array}{l}\text { Коллегиальный } \\
\text { Совещательный } \\
\text { Координационный }\end{array}$ \\
\hline 8 & $\begin{array}{l}\text { Научно-координационный совет по во- } \\
\text { просам сохранения родного языка и } \\
\text { традиционной культуры коренных ма- } \\
\text { лочисленных народов Севера Ханты- } \\
\text { Мансийского автономного округа - } \\
\text { ЮГРЫ }\end{array}$ & $\begin{array}{l}\text { Постановление Правительства ХМАО - } \\
\text { ЮГРЫ от } 13 \text { мая } 2011 \text { г. № 153-п (с из- } \\
\text { менениями на 19.04.2019) } \\
\text { Действующций }\end{array}$ & $\begin{array}{l}\text { Коллегиальный } \\
\text { Совещательный } \\
\text { Координационный }\end{array}$ \\
\hline 9 & $\begin{array}{l}\text { Экспертный совет по сохранению и раз- } \\
\text { витию чеченского языка при Главе Че- } \\
\text { ченской Республики }\end{array}$ & $\begin{array}{l}\text { Указ Главы Чеченской Республики от } \\
17 \text { мая } 2019 \text { г. № } 61 \text { (с изменениями на } \\
30 \text { декабря } 2019 \text { г.) } \\
\text { Действующции }\end{array}$ & $\begin{array}{l}\text { Совещательный } \\
\text { Консультативный }\end{array}$ \\
\hline 10 & Экспертный совет по ненецкому языку & $\begin{array}{l}\text { Приказ Департамента региональной по- } \\
\text { литики Ненецкого автономного округа } \\
\text { от } 15 \text { августа } 2016 \text { г. № } 10 \\
\text { Действующий }\end{array}$ & Координационный \\
\hline 11 & $\begin{array}{l}\text { Совет по развитию языков в Республике } \\
\text { Саха (Якутия) при Главе Республики } \\
\text { Саха (Якутия) }\end{array}$ & $\begin{array}{l}\text { Указ Главы Республики Саха (Якутия) } \\
\text { от } 21 \text { февраля } 2019 \text { г. № } 384 \text { (в редакции } \\
\text { от } 28.12 .2019 \text { г. № 962) } \\
\text { Действующции }\end{array}$ & $\begin{array}{l}\text { Консультативный } \\
\text { Координационный }\end{array}$ \\
\hline 12 & $\begin{array}{l}\text { Совет по адыгейскому языку при Главе } \\
\text { Республики Адыгея }\end{array}$ & $\begin{array}{l}\text { Указ Главы Республики Адыгея от } 1 \text { ав- } \\
\text { густа } 2003 \text { г. № } 120 \text { (с изменениями от } \\
12.02 .2020 \text { г. № 13) } \\
\text { Действующий }\end{array}$ & $\begin{array}{l}\text { Консультативный } \\
\text { Координационный }\end{array}$ \\
\hline 13 & $\begin{array}{l}\text { Совет по сохранению и развитию хакас- } \\
\text { ского языка, культуры и развитию этно- } \\
\text { туризма при Правительстве Республики } \\
\text { Хакасия }\end{array}$ & $\begin{array}{l}\text { Постановление Президиума Правитель- } \\
\text { ства Республики Хакасия от } 29 \text { августа } \\
2018 \text { г.№ 124-П, с изменениями на } \\
18 \text { февраля } 2020 \text { г. № } 23 \text {-п } \\
\text { Действующчий }\end{array}$ & Координационный \\
\hline 14 & $\begin{array}{l}\text { Совет по алтайскому языку при Главе } \\
\text { Республики Алтай, Председателе Пра- } \\
\text { вительства Республики Алтай }\end{array}$ & $\begin{array}{l}\text { Указ Главы Республики Алтай, Предсе- } \\
\text { дателя Правительства Республики Ал- } \\
\text { тай от } 9 \text { июня } 2015 \text { г. № 167-у } \\
\text { Действующций }\end{array}$ & Координационный \\
\hline 15 & $\begin{array}{l}\text { Общественный совет по русскому языку } \\
\text { при Мэре Москвы }\end{array}$ & $\begin{array}{l}\text { Распоряжение Мэра Москвы от } 18 \text { ок- } \\
\text { тября } 1999 \text { г. № 1169-РМ } \\
\text { Действующций }\end{array}$ & Консультативный \\
\hline 16 & $\begin{array}{l}\text { Консультативный Совет при главе ад- } \\
\text { министрации города Екатеринбурга по } \\
\text { вопросам межнационального и меж- } \\
\text { конфессионального согласия, поддерж- } \\
\text { ки и развития языков и культуры наро- } \\
\text { дов Российской Федерации, проживаю- } \\
\text { щих на территории муниципального об- } \\
\text { разования «Город Екатеринбург», реа- } \\
\text { лизации прав национальных мень- } \\
\text { шинств, обеспечения социальной и } \\
\text { культурной адаптации мигрантов, про- } \\
\text { филактике межнациональных (межэт- } \\
\text { нических) конфликтов }\end{array}$ & $\begin{array}{l}\text { Постановление Администрации города } \\
\text { Екатеринбурга от } 11 \text { февраля } 2014 \text { г. } \\
\text { № } 317 \text { (с изменениями на 14.04.2015 г.) } \\
\text { Действующций }\end{array}$ & Консультативный \\
\hline
\end{tabular}


Окончание таблиць 2

End of Table 2

\begin{tabular}{|c|c|c|c|}
\hline 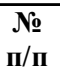 & Наименование института & Дата создания, вид НПА & $\begin{array}{c}\text { Профиль } \\
\text { деятельности }\end{array}$ \\
\hline 17 & $\begin{array}{l}\text { Совет при Правительстве Пензенской } \\
\text { области по вопросам развития русского } \\
\text { языка }\end{array}$ & $\begin{array}{llll}\text { Распоряжение } & \text { Правительства } \\
\text { ской области от } 17 \text { апреля } & 2017 \text { г. } \\
\text { № 175-рП } & & & \\
\text { Действующий } & & & \end{array}$ & Совещательный \\
\hline 18 & $\begin{array}{l}\text { Совет при Губернаторе Ульяновской } \\
\text { области по русскому языку }\end{array}$ & $\begin{array}{l}\text { Указ Губернатора Ульяновской области } \\
\text { от } 15 \text { апреля } 2020 \text { г. № } 54 \\
\text { Действующчий }\end{array}$ & $\begin{array}{l}\text { Координационный } \\
\text { Совещательный }\end{array}$ \\
\hline 19 & $\begin{array}{l}\text { Совет при Главе Республики Карелия } \\
\text { по русскому языку }\end{array}$ & $\begin{array}{l}\text { Указ главы РК от } 1 \text { августа } 2016 \text { г. № } 99 \\
\text { Действующий }\end{array}$ & Совещательный \\
\hline 20 & $\begin{array}{l}\text { Координационный Совет по вопросам } \\
\text { реализации Республиканской целевой } \\
\text { программы «Государственная поддерж- } \\
\text { ка карельского, вепсского и финского } \\
\text { языков в Республике Карелия на 2006- } \\
2010 \text { гг.» }\end{array}$ & - & Координационный \\
\hline 21 & $\begin{array}{l}\text { Совет по реализации законодательства о } \\
\text { языках Республики Татарстан при Ка- } \\
\text { бинете Министров Республики Татар- } \\
\text { стан }\end{array}$ & $\begin{array}{l}\text { Постановление Кабинета Министров } \\
\text { Республики Татарстан от } 27 \text { июня } \\
2008 \text { г. № } 451 \text { « дальнейших мерах по } \\
\text { реализации законодательства о языках } \\
\text { Республики Татарстан (с изменениями } \\
\text { на } 16.05 .2018 \text { г.) } \\
\text { Действующєий }\end{array}$ & $\begin{array}{l}\text { Координационный } \\
\text { Совещательный }\end{array}$ \\
\hline 22 & $\begin{array}{l}\text { Комиссия при Президенте Республики } \\
\text { Татарстан по вопросам сохранения и } \\
\text { развития татарского языка }\end{array}$ & $\begin{array}{l}\text { Указ Президента Республики Татарстан } \\
\text { от } 6 \text { июля } 2020 \text { г. № УП- } 384 \\
\text { Действующчий }\end{array}$ & Консультативный \\
\hline 23 & $\begin{array}{l}\text { Общественный совет при Губернаторе } \\
\text { Брянской области по поддержке разви- } \\
\text { тия библиотечного дела и содействию } \\
\text { развитию русского языка }\end{array}$ & $\begin{array}{l}\text { Постановление Администрации Брян- } \\
\text { ской области от } 8 \text { мая } 2007 \text { г. № } 320 \\
\text { (с изменениями на } 13 \text { марта } 2009 \text { г.) } \\
\text { Не действующзй документ } \\
\text { Постановление Администрации области } \\
\text { утратило силу в соответствии с Поста- } \\
\text { новлением Администрации области от } \\
17 \text { августа } 2010 \text { г. № } 815 \text { «О создании } \\
\text { общественного совета при Губернаторе } \\
\text { Брянской области по культуре» }\end{array}$ & Консультативный \\
\hline 24 & $\begin{array}{l}\text { Совет по русскому языку при Губерна- } \\
\text { торе Калужской области }\end{array}$ & $\begin{array}{l}\text { Постановление Губернатора Калужской } \\
\text { области от } 25 \text { мая } 2004 \text { г. № } 364 \text { (утра- } \\
\text { тил силу на основании Постановления } \\
\text { Губернатора Калужской области от } \\
17 \text { июня } 2015 \text { г. № } 242 \text { ) } \\
\text { Не действующий документ }\end{array}$ & Совещательный \\
\hline
\end{tabular}

Перспектива придания курсу языкового регулирования свойств институциональной целостности, таким образом, предполагает выстраивание более интегрированных по вертикали и горизонтали агентств.

В исследовательских дискурсах далее наблюдается довольно широкий разброс оценок относительно обособления языковой политики в качестве самостоятельной области. Есть точка зрения, изложенная в политико-правовом контексте, согласно которой «го- сударственная языковая политика Российской Федерации обладает достаточным набором формализованных и обособленных целей, а также иных свойств и качеств для выделения ее в отдельный тип государственной политики по виду деятельности» [2]. Специалисты в области собственно языкознания склонны к более сдержанному видению предмета. В России, согласно оценкам В.М. Алпатова, на общегосударственном уровне языковая политика «во многом осуществля- 


\section{ПОЛИТИЧЕСКИЙ ПРОЦЕСС В СОВРЕМЕННОЙ РОССИИ}

ется стихийно» и не содержит устойчивой модели [1, с. 30].

Институциональная модель в этой сфере может состояться как проективно и идеологически сформированный режим политикоязыкового устройства. Помимо упрочения позиций государственного языка (интралингвальные аспекты) такая модель требуется для стабилизации общенациональной и региональных языковых ситуаций (интерлингвальные аспекты). В центре всего проблемного поля здесь располагается институт двуязычия и реже - многоязычия. Упомянутая амбивалентность в данном случае выражается в отсутствии баланса между de jure, в рамках нормативно-правовых актов, в том числе в декларированных принципах программноцелевых документов, с одной стороны, и функциональными параметрами функционального распределения языков на региональных уровнях, или социолингвистическими состояниями de facto, с другой стороны.

В общественно значимых сферах российских республик нерусские языки используются в лучшем случае ограниченно, утрачивая свою функциональность. Это происходит во многом из-за отсутствия внятно артикулированного стратегического целеполагания. В начале столетия на правительственном уровне, что, кстати, составило редкий и практически исключительный случай, была выдвинута формула: «Основой языковой политики, включая политику в области образования, является стратегия сохранения и упрочения сбалансированного национально-русского и руссконационального двуязычия, при котором обеспечивается знание русского языка как государственного всем населением Российской Федерации, поощряется изучение национальных языков населением ее республик и создаются условия для гармоничного взаимодействия русского языка с другими языками Российской Федерации» [8]. В последующем двуязычие как норма стратегического планирования стала упоминаться на федеральном уровне все реже и реже. Нормативно-правовые конструкции о «равноправном функционировании языков» или об их паритетном использовании во всех общественных сферах не отвечают реальному состоянию социально-коммуникативных сред в российских регионах.
Результаты. По итогам рассмотрения уместно предложить некоторые подходы.

Первое. Насущный характер принадлежит задачам профессионально-общественной экспертизы нормативно-правовых институтов языковой политики как по отношению к русскому языку, так и к культурно-языковому многообразию. Очевидна потребность в обобщающем и программирующем доктринальном документе об основах государственной языковой политики, который бы определял институциональные ориентиры. Идеологические установки в этой области могли бы гарантировать отход от представлений о языковой политике как об «игре с нулевой суммой», когда одни виды идентичностей, - и не только этнокультурные, но и социокультурные, - предполагается усиливать исключительно за счет других [7]. Сегодня, по-видимому, уже сложился консенсус относительно того, что действующее российское законодательство требуется избавить от декларативности, терминологического разнобоя, неопределенности, избыточной диспозитивности большинства нормативных конструкций. Его необходимо модернизировать, адаптировав к меняющимся социолингвистическим и культурно-информационным реалиям.

Будущность российской языковой политики как целостной системы управленческой практики связана, вероятно, не только с учреждением новых организационных акторов или бюрократических «действующих лиц», но, прежде всего, с институциональной кодификацией дискурсивных, смысловых ориентиров, или, как иногда говорят, «языковых идеологий».

Второе. Можно уверенно предположить, что новым пространством институционализации станет языковая политика ONLINE как меры публично-политического характера и разноплановые усилия в сфере национально-языковых отношений в виртуальном пространстве, которые могут осуществляться как традиционными агентами макроуровня с волевыми установками и интересами «сверху - вниз», так и социальными акторами, чья деятельность по изменению языковых практик может быть охарактеризована как «снизу - вверх».

Интернет все более зримо становится и средой, и ареной соотнесения различных интересов, и инструментом языкового регулиро- 
вания. Всемирная сеть - это своего рода (условно говоря) независимая переменная в политико-языковых отношениях. Дело, прежде всего, в том, что виртуальная активность многообразных участников в этой сфере способна превосходить привычные параметры демографической мощности языков (численности говорящих). Об этом говорит статистика (табл. 3).

Следовательно, языковая политика будущего во многом будет определяться в киберпространстве, а не только в традиционных институциях образования, СМИ, профессионального искусства и пр.

Третье. Целостная языковая политика нереализуема вне соответствующих институтов информационно-аналитического обеспечения. Картину актуальных языковых и социально-коммуникативных ситуаций в стране и ее регионах крайне затруднительно анализировать без достоверной эмпирической базы в виде сведений о присутствии языков в образовательной, культурной, информационной сферах и современных информационно-коммуникативных технологиях, в практике управления на всех уровнях. Сведения, относящиеся к этой области публичной политики, должны быть систематизированы, сопоставимы во времени и пространстве, верифицируемы, но главное - доступны общественности. Это необходимо, кроме всего прочего, для того, чтобы элиминировать действие факторов эмоциональной политизации и рисков психологического недоверия. При этом речь не должна идти о том, что принято квалифицировать как «тиранию показателей»-пресловутых рейтингов, мониторингов. Реально намеченный институциональный вектор здесь - задача составления ежегодного доклада в органы исполни- тельной власти (Распоряжение Правительства РФ от 28.12.2018 г. № 2985-р, п. 28).

Четвертое. Меняющаяся институциональная среда языковой образовательной политики нуждается в обобщении тех тенденций, которые выявляются в контексте принципов добровольности при выборе языков, изучаемых в качестве родных. Несомненна потребность в достоверных данных на предмет реального присутствия этих языков в учебном процессе и конкретных форматах и объемах на конкретных ступенях образовательного процесса, а не простая констатация того, что язык «представлен» или «используется». В противном случае в распоряжении практиков-профессионалов, управленцев, аналитиков и общественности может оставаться лишь формальная картина, непригодная для принятия институциональных решений. В этой сфере далее можно было бы реабилитировать концепт «национальной школы», а не «школы с родным (нерусским) и русским (неродным) языками обучения» [6, c. 16]. Дело в том, что «национальная школа», в которой родные языки народов страны используются в качестве средства преподавания - это жизненный институт культурно-лингвистического воспроизводства этнических сообществ в их полноценной «самости». В сегодняшних условиях и, прежде всего, под воздействием урбанизации и бурного развития масс-медиа, виртуального контента эта составляющая школьного дела на глазах сворачивается. В ближайшей перспективе культурная жизнь народов России может остаться без профессиональных «семиотических работников», обладающих должными языковыми компетенциями в идеоэтническом смысле.

\section{Таблица 3. Динамика использования языков на веб-сайтах 2011-2019 гг., \%}

Table 3. Dynamics of the use of languages on websites 2011-2019, \%

\begin{tabular}{|l|c|c|c|}
\hline \multicolumn{1}{|c|}{ Язык } & $\mathbf{2 0 1 1}$ & $\mathbf{0 1 . 0 1 . 2 0 1 9}$ & $\mathbf{2 1 . 0 7 . 2 0 1 9}$ \\
\hline Английский & 57,2 & 54,0 & 54,0 \\
\hline Русский & 4,8 & 6,0 & 6,1 \\
\hline Немецкий & 4,7 & 6,0 & 5,7 \\
\hline Испанский & 6,5 & 4,9 & 5,0 \\
\hline Французский & 4,6 & 4,0 & 3,9 \\
\hline Японский & 3,9 & 3,4 & 3,5 \\
\hline Португальский & 2,0 & 2,9 & 2,9 \\
\hline
\end{tabular}

Примечание. Источник: [5]. 


\section{ПОЛИТИЧЕСКИЙ ПРОЦЕСС В СОВРЕМЕННОЙ РОССИИ}

Пятое. Институты языковой политики как системы формализованных процедур и решений требуют того, чтобы быть дополненными институтами языкового культивирования, языкового менеджмента. Решающая роль при этом принадлежит и будет принадлежать элитам, образованному политическому «классу», символьным сегментам элиты. Если лидирующие в жизни общества группы не смогут взять на себя институциональную миссию авторитетов в области языкового функционирования, процессы коммуникативно-языковой деградации только продолжатся.

\section{ПРИМЕЧАНИЕ}

1 Исследование выполнено при финансовой поддержке РФФИ и ЭИСИ в рамках научного проекта № 20-011-31601 «"Политика языка”: геолингвистические контексты и модусы участия».

The reported study was funded by RFBR and EISR, project number 20-011-31601 "Politics of Language': Geolinguistic Contexts and Modi of Participation".

\section{СПИСОК ЛИТЕРАТУРЫ}

1. Алпатов, В. М. Языковая политика в современном мире / В. М. Алпатов // Языковое единство и языковое разнообразие в полиэтническом государстве : Междунар. конф., Москва, 14-17 ноября 2018 г. : доклады и сообщения. - М. : Языки народов мира, 2018. - С. 24-33.

2. Бенедиктов, Н. А. О правовых основах государственной языковой политики / Н. А. Бенедиктов, А. П. Бердашкевич // Мир русского слова. 2003. - № 2. - Электрон. текстовые дан. - Режим доступа: https:// www.gramota/ru/biblio/magazines/ mrs/mrs2003-02/ (дата обращения: 20.08.2020). - Загл. с экрана.

3. Заседание Совета по русскому языку. В Екатерининском зале Кремля состоялось заседание Совета при Президенте по русскому языку. 5 ноября 2019 года. - Электрон. текстовые дан. - Режим доступа:// http://www.kremlin.ru/events/president/ news/61986 (дата обращения: 20.08.2020). - Загл. с экрана.

4. Кондрашкина, Е. А. Сферы общения и язык / Е. А. Кондрашкина // Язык и общество. Энциклопедия. - М. : Азбуковник, 2016. - С. 460-464.

5. Коптлеуов, А. Кому мешает кириллица, или Приближает ли латиница Казахстан к цивилизации? / А. Коптлеуов // Литературная газета. - 2020. -
18 нояб. (№ 46 (6761)). - Электрон. текстовые дан. Режим доступа://https://gz.ru/article/-46-6761-18-112020/ (дата обращения: 18.11.2020). - Загл. с экрана.

6. Мартынова, М. Ю. Языковое богатство России в аспекте федеральной политики и региональных инициатив / М. Ю. Мартынова // Измерение культурного многообразия. Языковая ситуация, переписи, полевая статистика / ред. М. Ю. Мартынова, В. В. Степанов. - М. : ИЭА РАН, 2019. - С. 7-20.

7. Миятович, Д. Языковая политика должна учитывать разнообразие, защищать права меньшинств и снижать напряжение в обществе / Д. Миятович // [Дневник прав человека. Страсбург 29.10.2019]. - Электрон. текстовые дан. - Режим доступа: https://www.coe.int/ru/web/commissioner//language-policies-should-accomodate-diversityprotect-minority-rights-and-defuse-tensions (дата обращения: 25.08.2020). - Загл. с экрана.

8. О федеральной целевой программе «Русский язык» на 2002-2005 годы : постановление Правительства Российской Федерации от 27 июня 2001 г. № 483 (в ред. Постановления Правительства РФ от 25.11.2003 № 712, от 06.09.2004 № 459). - Электрон. текстовые дан. - Режим доступа: https://normativ. kontur.ru/document?modueld $=1 \&$ documentld $=78454$ (дата обращения: 05.09.2020). - Загл. с экрана.

9. Публичная политика: Институты, цифровизация, развитие : коллектив. моногр. / под ред. Л. В. Сморгунова. - М. : Аспект Пресс, 2018. - 349 с.

10. Современная политическая наука: Методология / отв. ред. О. В. Гаман-Голутвина, А. И. Никитин. - М. : Аспект Пресс, 2019. - 776 с.

11. Устарханов, Р. И. Эволюция эвфемизма: от цензуры к политкорректности / Р. И. Устарханов // Конфликт в языке и коммуникации : сб. ст. / сост. и отв. ред. Л. Л. Федорова. - М. : Изд-во РГГУ, 2011.- С. 55-66.

12. Хауген, Э. Лингвистика и языковое планирование / Э. Хауген // Новое в лингвистике. Вып. VII. Социолингвистика. - М. : Прогресс, 1975. - C. 441-472.

13. Cooper, R. Language planning and social change / R. Cooper. - Cambridge : Cambridge Univ. Press, 1989. $-216 \mathrm{p}$.

14. Fitzsimmons-Doolan, Sh. Language ideologies of institutional language policy: exploring variability by language policy register / Sh. Fitzsimmons-Doolan // Language Policy. - 2019. - № 18. - P. 169-189. DOI: https:// doi.org/10.1007/s10993-018-9479-1.

15. Haarmann, H. The Politics of Language Spread / H. Haarmann // Sociolinguistics: an international handbook of the science of language and society = Sozioliguistik: eininternationales Handbuch zur Wissenschaft von Sprache und Gesellshaft. $2^{\text {nd }}$ completely rev. \& extended ed. - Vol. 2. - Berlin ; N. Y. : Walter de Gruiter, 2005. - P. 1653-1667. 
16. Haught, M. Conversational interaction / M. Haught // The Cambridge Handbook of Pragmatics / ed. by Keith Allan and Kasia M. Jaszczolt. - Cambridge : Cambridge Univ. Press, 2012. - P. 251-276.

17. Kaplan, R. Language Planning. From Practice to Theory / R. Kaplan, R. Baldauf. - Clevedon : MULTILINGUAL MATTERS LTD, 1997. - 403 p.

18. Pennycook, A. Postmodernism in Language Policy / A. Pennycook // An Introduction to Language Policy. Theory and Method / ed. by Thomas Ricento. Oxford : Blackwell Publishing, 2006. - P. 60-76.

\section{REFERENCES}

1. Alpatov V.M. Iazykovaia politika v sovremennom mire [Language Policy in Modern World]. Iazykovoe edinstvo i iazykovoe raznoobrazie $v$ polietnicheskom gosudarstve: Mezhdunar. konf., Moskva, 14-17 noyabrya 2018 g.: doklady $i$ soobshcheniya [Language Unity and Language Diversity in Polyethnic Country. International Conference, Moscow, 14-17 November 2018. Reports and Presentations]. Moscow, Iazyki narodov mira Publ., 2018, pp. 24-33.

2. Benediktov N.A., Berdashkevich A.P. O pravovykh osnovakh gosudarstvennoi iazykovoi politiki [On the Legal Foundations of the State Language Policy]. Mir russkogo slova [The World of Russian Word], 2003, no. 2. URL: http://www.gramota/ $\mathrm{ru} / \mathrm{biblio} / \mathrm{magazines} / \mathrm{mrs} / \mathrm{mrs} 2003-02 /$ (accessed 20 August 2020).

3. Zasedanie Soveta po russkomu iazyku. $V$ Ekaterininskom zale Kremlia sostoialos zasedanie Soveta pri Prezidente po russkomu iazyku. 5 noiabria 2019 goda [Meeting of Council on Russian Language. A Meeting of the Presidential Council on the Russian Language Took Place in the Catherine Hall of the Kremlin. November 5, 2019]. URL: http://www. kremlin.ru/events/president/news/61986 (accessed 20 August 2020).

4. Kondrashkina E.A. Sfery obshcheniia i iazyk [Spheres of Communication and Language]. Iazyk $i$ obshchestvo. Entsiklopediia [Language and Society. Encyclopedia]. Moscow, Azbukovnik Publ., 2016, pp. 460-464.

5. Koptleuov A. Komu meshaet kirillica, ili Priblizhaet li latinica Kazahstan k civilizacii? [Who is Hindered by the Cyrillic Alphabet, or Does the Latin Alphabet Bring Kazakhstan Closer to Civilization?]. Literaturnaja gazeta [Literary Newspaper], 2020, November 18 (no. 46 (6761)). URL: https://lgz.ru/article/ -46-6761-18-11-2020/ (accessed 18 November 2020).

6. Martynova M.Iu. Iazykovoe bogatstvo Rossii $\mathrm{v}$ aspekte federalnoi politiki i regionalnykh initsiativ [Linguistic Wealth of Russia in the Aspect of Federal
Policy and Regional Initiatives]. Izmerenie kulturnogo mnogoobraziia. Iazykovaia situatsiia, perepisi, polevaia statistika [Measuring Cultural Diversity. Language Situation, Censuses, Field Statistics]. Moscow, IEA RAN, 2019, pp. 7-20.

7. Miiatovich D. Iazykovaia politika dolzhna uchityvat raznoobrazie, zashchishchat prava menshinstv i snizhat napriazhenie $\mathrm{v}$ obshchestve [Language Policies Should Accommodate Diversity, Protect Minority Rights and Defuse Tensions]. Dnevnik prav cheloveka [Human Rights Comment]. Strasbourg, 2019. URL: https://www.coe.int/ru/web/ commissioner/-/language-policies-shouldaccomodate-diversity-protect-minority-rights-anddefuse-tensions (accessed 25 August 2020).

8. O federalnoi tselevoi programme «Russkii iazyk» na 2002-2005 gody: postanovlenie Pravitelstva Rossiiskoi Federatsii ot 27 iiunia 2001 g. № 483 (v red. Postanovleniia Pravitelstva RF ot 25.11.2003 № 712, ot 06.09.2004 № 459) [On the Federal Target Program "Russian Language" for 2002-2005. Decree of the Government of the Russian Federation of June 27, 2001 no. 483 (as Amended by the Decree of the Government of the Russian Federation of 25.11 .2003 no. 712 , of 06.09 .2004 no. 459)]. URL: https://normativ.kontur.ru/ document?modueld $=1 \&$ document $1 \mathrm{~d}=78454$ (accessed 5 September 2020).

9. Smorgunov L.V., ed. Publichnaia politika: Instituty, tsifrovizatsiia, razvitie: kollektiv. monogr. [Public Policy: Institutions, Digitalization, Development: Collective Monograph]. Moscow, Aspect Press Publ., 2018. 349 p.

10. Gaman-Golutvina O.V., Nikitin A.I. eds. Sovremennaia politicheskaia nauka: Metodologiia [Contemporary Political Science: Methodology]. Moscow, Aspect Press Publ., 2019. 776 p.

11. Ustarkhanov R.I. Evoliutsiia evfemizma: ot tsenzury k politkorrektnosti [Evolution of Euphemism: from Censorship to Political Correctness]. Fedorova L.L. ed. Konflikt v iazyke $i$ kommunikatsii: sb. st. [Conflict in Language and Communication. Collection of Articles]. Moscow, Izd-vo RGGU, 2011, pp. 55-66.

12. Khaugen E. Lingvistika i iazykovoe planirovanie [Linguistics and Language Planning]. Novoe v lingvistike. Vyp. VII. Sotsiolingvistika [New in Linguistics. Iss. $7^{\text {th }}$. Sociolinguistics]. Moscow, Progress Publ., 1975, pp. 441-472.

13. Cooper R. Language Planning and Social Change. Cambridge, Cambridge Univ. Press, 1989. 216 p.

14. Fitzsimmons-Doolan Sh. Language Ideologies of Institutional Language Policy: Exploring Variability by Language Policy Register. Language Policy, 2019, no. 18 , pp. 169-189. DOI: https://doi.org/10.1007/ s10993-018-9479-1. 


\section{ПОЛИТИЧЕСКИЙ ПРОЦЕСС В СОВРЕМЕННОЙ РОССИИ}

15. Haarmann H. The Politics of Language Spread. Sociolinguistics: An International Handbook of the Science of Language and Society = Sozioliguistik: Eininternationales Handbuch zur Wissenschaft von Sprache und Gesellshaft. $2^{\text {nd }}$ completely rev. \& extended ed., vol. 2, Berlin, New York, Walter de Gruiter, 2005, pp. 1653-1667.

16. Haught M. Conversational Interaction. Keith Allan and Kasia M. Jaszczolt eds. The Cambridge
Handbook of Pragmatics. Cambridge, Cambridge Univ. Press, 2012, pp. 251-276.

17. Kaplan R., Baldauf R. Language Planning. From Practice to Theory. Clevedon, MULTILINGUAL MATTERS LTD, 1997. $403 \mathrm{p}$.

18. Pennycook A. Postmodernism in Language Policy. Ricento T., ed. An Introduction to Language Policy. Theory and Method. Oxford, Blackwell Publishing, 2006, pp. 60-76.

\section{Information About the Authors}

Ol'ga B. Yanush, Candidate of Sciences (Politics), Associate Professor, Department of Sociology, Political Science and Law, Kazan State Power Engineering University, Krasnosel'skaja St, 51, 420066 Kazan, Russian Federation, yanush_ob@yahoo.com, https://orcid.org/0000-0002-5606-5984

Nail' M. Mukharyamov, Doctor of Sciences (Politics), Professor, Head of the Department of Sociology, Political Science and Law, Kazan State Power Engineering University, Krasnosel'skaja St, 51, 420066 Kazan, Russian Federation, n.mukharyamov@yandex.ru, https://orcid.org/0000-0002-3810-824X

\section{Информация об авторах}

Ольга Борисовна Януш, кандидат политических наук, доцент кафедры социологии, политологии и права, Казанский государственный энергетический университет, ул. Красносельская, 51, 420066 г. Казань, Российская Федерация, yanush_ob@yahoo.com, https://orcid.org/0000-0002-5606-5984

Наиль Мидхатович Мухарямов, доктор политических наук, профессор, заведующий кафедрой социологии, политологии и права, Казанский государственный энергетический университет, ул. Красносельская, 51, 420066 г. Казань, Российская Федерация, n.mukharyamov@yandex.ru, https://orcid.org/0000-0002-3810-824X 